\title{
Occupational Health Safety of Health Professionals and Associated Factors During COVID-19 Pandemics at North Showa Zone, Oromia Regional State, Ethiopia
}

This article was published in the following Dove Press journal:

Risk Management and Healthcare Policy

\author{
Dejene Hailu (D) \\ Mengistu Benayew (D) \\ Tiliksew Liknaw' \\ Muluken Ayenew' \\ Agumas Fentahun Ayalew ${ }^{2}$ \\ Bizuneh Ayano ${ }^{2}$ \\ Addis Adera (iD ${ }^{2}$ \\ Mengistu Tesema ${ }^{2}$ \\ Andualem Gezahegn ${ }^{3}$ \\ Tadesse Birhanu ${ }^{4}$ \\ Eshetu Wendimu ${ }^{5}$ \\ 'Department of Nursing, College of \\ Health Sciences, Salale University, Fitche, \\ Ethiopia; ${ }^{2}$ Department of Public Health, \\ College of Health Sciences, Salale \\ University, Fitche, Ethiopia; ${ }^{3}$ Department \\ of Midwifery, College of Health Science, \\ Salale University, Fitche, Ethiopia; \\ ${ }^{4}$ Tropical and Infectious Disease, Salale \\ University, Fitche, Ethiopia; ${ }^{5}$ Research \\ and Community Services Vice President, \\ Salale University, Fitche, Ethiopia
}

Correspondence: Dejene Hailu Email dejenehailu77@yahoo.com
Background: Coronavirus disease 19 was observed as a pandemic and caused many community health problems that resulted in Global issues. It causes death for many individuals including health professionals. This study aimed to determine the occupational health safety of health professionals and associated factors during COVID-19 pandemic at North Showa.

Methods: Institutions-based Cross-sectional study was conducted using a simple random sampling technique from May 10 to June 15, 2020. Interviewer-administered questioners were used, and data were entered into Epi-data version 3.1 and exported to SPSS 23 for analysis. Bi-variable logistic regression was carried out to select candidate variables with a cutoff point $<0.2$. Finally, multivariable logistic regression was conducted to identify significant variables. An adjusted odds ratio with $95 \% \mathrm{CI}$ at a $5 \%$ level of significance was used to measure the strength of association. P-value $<0.05$ indicated a significant association between variables.

Results: A total of 280 health professionals participated with a $92.72 \%$ response rate. Of which $57.9 \%(n=162)$ were males while $42.1 \%(n=118)$ females. Of total $48.9 \%(n=137)$ (95\% CI: 43.2, 55.0) health professionals had poor occupational health and safety. Availability of soap and bleach ( $\mathrm{AOR}=2.50 ; 1.439,4.356)$, Possibility of isolate COVID19 suspected clients $(\mathrm{AOR}=2.525 ; 1.690,5.062)$, Availability of infections prevention and control program standards and policy $(\mathrm{AOR}=2.329 ; 1.325,4.092)$, Availability of policy and procedure to prevent COVID-19 $(\mathrm{AOR}=2.427 ; 1.389,4.240)$ were significantly associated. Conclusion: The result suggested that occupational health safety was generally low in the study area. Therefore, a preventive measure such as the use of personal protective equipment and adherence to hand hygiene practice and Infection prevention policy could reduce the spread of COVID-19 and further study should be conducted to generate more evidence on determinants of occupational health safety.

Keywords: occupational health, COVID-19, safety, Ethiopia

\section{Introduction}

Coronavirus had been observed as an epidemic disease since 2003 and it has also caused many community health problems that resulted in Global serious issues. Moreover, these cases consecutively occurred as severe acute respiratory syndrome (SARS), middle east respiratory syndrome (MERS), and Coronavirus diseases 2019 (COVID-19). ${ }^{1}$ 
Public health disasters are threatening the world with the emergence and spread of 2019 novel coronavirus (2019-nCoV) or the severe acute respiratory syndrome coronavirus 2 (SARS-CoV-2). The virus originated in bats and was transmitted to humans through yet unknown intermediary animals in Wuhan, Hubei province, China in December 2019. ${ }^{2}$

According to the Worldometer report, the outbreak has been confirmed in over 8,708,008 cases (of which 183,020 new cases) worldwide and resulted in more than 461,715 deaths. In Africa, 216,999 confirmed cases, and 4874 deaths were reported. Moreover, in Ethiopia, 4469 total confirmed cases of which 399 confirmed new cases and 72 deaths were reported as of June 21,2020, and that was at the community transmission stage. ${ }^{3}$

As the outbreak is a global pandemic, it is important to note that the problem needs more attention all over the world especially in Africa because African countries have limited healthcare structure to control the pandemic. ${ }^{4}$ Prevention of transmission in healthcare settings is the priority to slow down the demand for particular healthcare setting such as intensive care unit beds, safeguarding risk groups, protecting healthcare workers, and minimizing the transfer of the cases to other healthcare facilities. ${ }^{5}$ Healthcare professionals are at the front line of the COVID-19 due to their direct contact with patients during triage on acute respiratory symptoms, so they should keep the distance at least 2 meters, and patients should wear face masks. During the care of these patients, the healthcare workers (HCW) should wear necessary personal protective equipment (PPE) and adherence to hand hygiene practice. $^{6}$

Thus, poor WASH (Water, Sanitation, and Hygiene) and infection prevention and control (IPC) lead to hospital-acquired infections and transmission of disease from health institutions to the community that worsens the outbreak and spread of infections. $^{7}$

According to World Health Organization Ethiopia is identified as one of the 13 high-risk African countries for coronavirus. According to a statement issued on Friday, February 1, 2020, WHO said the identified African nations have direct links or a high volume of travel to China. WHO put Ethiopia 12th risk nation among these 13 countries. ${ }^{8}$

Ethiopia confirms the first coronavirus case on 13 March 2020 in the country and the victim was later identified as a Japanese citizen who comes from Burkina Faso, after 43 days of WHO put under risk African country and after 103 days China confirmed the case in its territory. Ethiopia has reported its first case of the brand new coronavirus; the rustic's public wellbeing institute informed Reuters Information Company. The mayor of the capital Addis Ababa reported that "Eastern citizen was once the individual affected". 9 After 2 days of confirmed first coronavirus case, March 15 2020, three additional cases of the coronavirus were reported. ${ }^{10}$

\section{Occupational Health Safe Work Practices}

Are types of administrative controls that include procedures for safe and proper work used to reduce the duration, frequency, or intensity of exposure to a hazard. Safe work practices for SARS-CoV-2 include providing resources and a work environment that promotes personal hygiene, requiring regular hand washing, or using alcohol-based hand rubs that are used to minimize the transmission of infection in the working environment. ${ }^{11}$

Coronavirus disease 19 is a leading cause for the death of many individuals worldwide and many health professionals in Italy including doctors. More than 100 physicians and nurses were died due to COVID-19 and half of this were from Italy. A report from CDC indicates the United States of America 19\% of the total COVID-19 infected individuals were health professionals of which three-quarters were females. However, there is no evidence for the magnitude of COVID-19 infection in Ethiopia. ${ }^{12}$

In the beginning, the Ethiopian government and Ethiopian airlines do not take any measures even if the virus was widely spread among 134 countries. According to the Health Minister of Ethiopia, despite worsening situations in other countries, Ethiopia will not be enforcing a travel ban, although stating that the virus is in 134 countries. ${ }^{12}$ But the contact tracing started after the first confirmed case in Ethiopia. ${ }^{13}$ As soon as three additional confirmed cases the government of Ethiopia reacts as the following, on 16 March 2020, the office of the prime minister announced that schools, sporting events, and public gatherings shall be suspended for 15 days. ${ }^{14}$ On 20 March 2020, Ethiopian Airlines stopped flights to 30 countries affected by the coronavirus and announced that anyone entering the country should undergo a mandatory self-quarantine for 14 days. Night clubs in Addis Ababa are also to remain closed. ${ }^{14}$

The study on OHS of health professionals was the key to the improvement of the safety of health professionals and clients at the health institution. Also, used to reduce the spread of COVID-19 infection and decrease other 
work hazards; besides, health professionals must implement OHS at work and within the offices to make sure that their employees and clients are safe and healthy. Therefore, this study was aimed to assess the occupational health safety of health professionals and associated factors during COVID-19 epidemic in North Showa Zone, Oromia Regional State, Ethiopia.

\section{Research Questions}

- Do health professionals maintain their occupational health and safety during COVID-19 pandemics?

- What are the factors which affect the occupational health and safety of health professionals during COVID-19 Pandemics?

\section{Methods}

\section{Study Setting}

The study was conducted at all Public Hospitals in the North Shoa zone. North Shoa zone is one of the 20 zones found in the Oromia regional state. It has 24 districts and a total population of 1431,305 .

The zone has 63 Health centers and 5 public hospitals. Seven hundred and fifteen health professionals were working in these hospitals.

\section{Study Design and Period}

Institutional based cross-sectional study was conducted from May 10-June 15, 2020 on public Hospitals among health professionals.

\section{Source Population}

All health professionals working at all public hospitals in the North Shoa zone during the data collection period.

\section{Study Population}

All randomly selected professionals recruited and working at all public hospitals in the North Shoa zone during the data collection period were the study population.

\section{Inclusion and Exclusion Criteria}

Health professionals working at public hospitals in the North Shoa zone during the data collection period and who were volunteers to participate in this study were included. Health professionals who were on annual leave and severely sick were excluded from the study.

\section{Sample Size Determination and Sampling Procedure \\ Sample Size Determination}

The sample size was calculated using single population proportion formula using a proportion of $50 \%$ since no study was not conducted earlier. Considering 95\% confidence interval and 5\% marginal error with a $20 \%$ nonresponse rate, the sample size used in this study was calculated using simple population proportion formula.

$$
n_{i}=\left\{\frac{\left[\left(z_{\alpha / 2}\right)^{2} \cdot(p(1-p)]\right.}{d^{2}}\right\}
$$

$\mathrm{ni}=$ initial sample size.

$\mathrm{Z}=$ standard normal value at $95 \% \mathrm{CI}$ which is 1.96

$\mathrm{P}=$ proportion of occupational health safety which is 0.5 since no study was done previously.

$\mathrm{d}=$ possible margin of error tolerated which is $5 \%$.

$$
n=\frac{(1.96)^{2}(0.5)(0.5)}{(0.05)^{2}}=385
$$

Since the total population or the total number of health professionals in North Showa Zone hospitals 715 which is less than 10 thousand sample size correction formula considered.

$\mathrm{nf}=\mathrm{n} / 1+\mathrm{n} / \mathrm{N}=385 / 1+385 / 715=385 / 1+0.53846154=385 /$ $1.53846154=250.25=251$.

By adding a $20 \%$ non-response rate the final smallest required sample size will be

$$
=251+251 * 20 / 100=251+250.2=301.2=302 .
$$

\section{Sampling Procedure}

The study was conducted in five Hospitals; Fitche hospital, Muke Turi hospital, Shano hospital, Kuyu hospital, and Gundo Meskel hospital which were located in the North Shoa zone. The number of study participants allocated proportionally to each Hospital based on the number of health professionals each hospital owns. Therefore, the sample of each Hospital was calculated by multiplying the number of health professionals all hospitals have with the total sample size $(n=302)$, dividing by the total number of health professionals each hospital had. Based on their number of health professionals we involved, 71, 51, 68, 63, and 49 study participants from each hospital, respectively. The study participants were selected from each public Hospital by using a simple random sampling technique or lottery method (Figure 1).

\section{Data Collection Tool and Procedure}

Data were collected through interviewer-administered structured questionnaires. The data collection tools were 
originally prepared by the authors of this manuscript, through adapting and modifying from various works of literature. The questionnaire is prepared in English and translated to Afan Oromo and translated back to the English version to check the consistency. Fifteen health professionals were selected for data collection and supervision, ten for data collection, and five health professionals for supervision. The study participants were selected from each public Hospital by using a simple random sampling technique (lottery method).

\section{Data Quality Assurance}

Two days of training were given to data collectors and supervisors on the objective of the study, contents of the questionnaire (original tool prepared by authors of this manuscript), confidentiality, the right of respondents, and how to collect data. The pretest was conducted on $5 \%$ of the sample at Degem Health Center and the Cronbachs alpha value was 0.78 . To identify the reliability of the data collection instruments and findings, data collectors and supervisors were discussed on the questionnaire so that the tool was modified for any inconsistencies and ambiguity before actual data collection.

\section{Study Variables \\ Dependent Variable}

Occupational health safety

\section{Independent Variables}

Socio-economic variables: age, sex, educational level, religion, profession, monthly income, work experience, marital status, and ward

Availability of PPE and other disinfectants: accessibility of supplies; like Availability of PPE, water wash station, presence of IPCP policy and procedure towards COVID-19 prevention, staff training, screening, and monitoring, presence of staff infection, and prevention surveillance.

Engineering and administrative control: Restricting the number of staff entering the room, minimizing staff

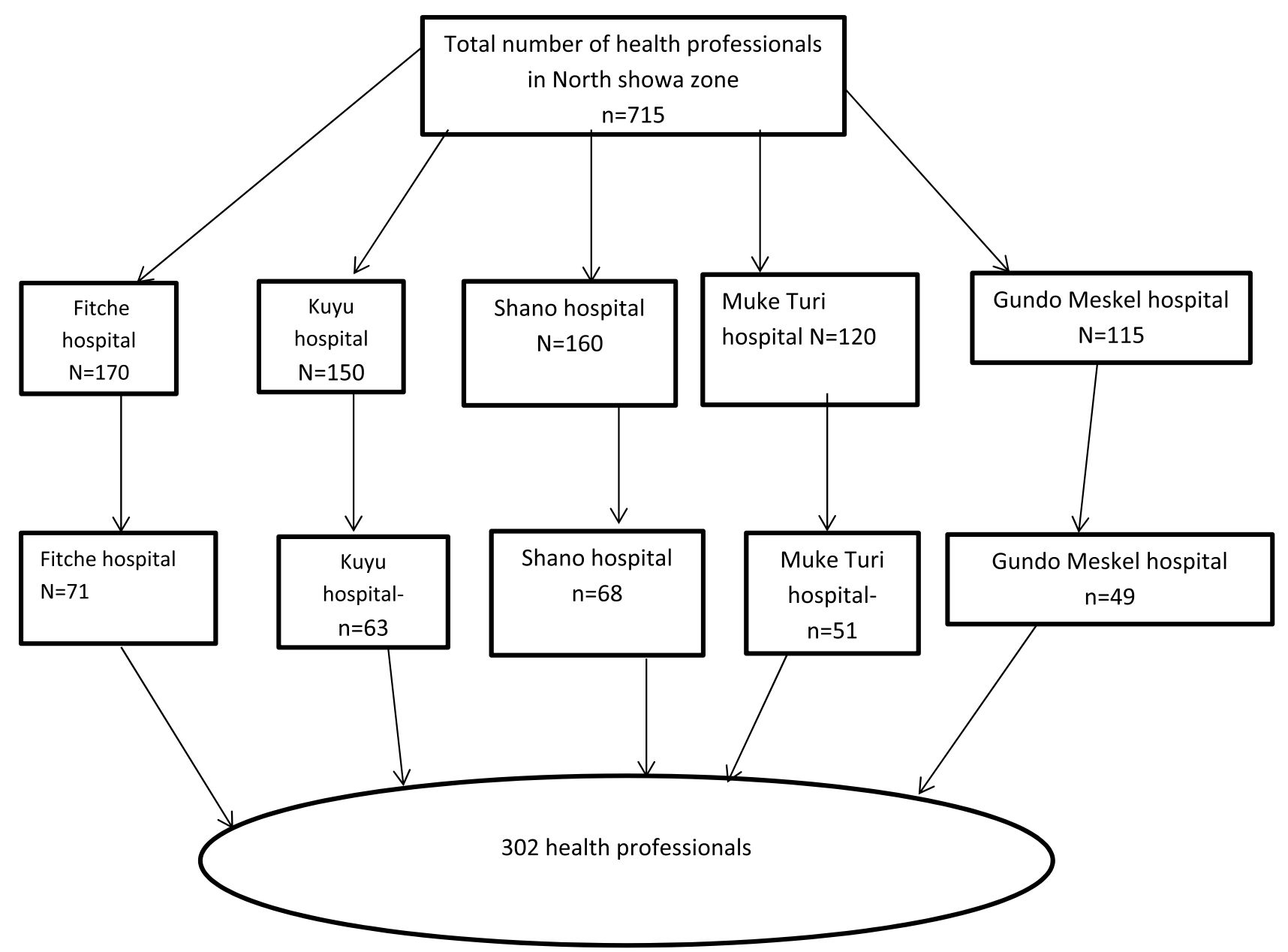

Figure I Schematic presentation of sampling procedure of a research project. 
Table I Socio-Demographic Characteristic of Health Professionals at Hospitals in North Showa Zone, Oromia Regional State, Ethiopia, 2020

\begin{tabular}{|c|c|c|c|c|c|}
\hline \multirow[t]{3}{*}{ Variables } & \multirow[t]{3}{*}{ Category } & \multicolumn{4}{|c|}{ Occupational Health and Safety } \\
\hline & & \multirow{2}{*}{$\begin{array}{c}\text { Unfavorable } \\
\text { Frequency (\%) }\end{array}$} & \multirow{2}{*}{$\begin{array}{c}\text { Favorable } \\
\text { Frequency (\%) }\end{array}$} & \multirow{2}{*}{$\begin{array}{c}\text { Total } \\
\text { Frequency (\%) }\end{array}$} & \multirow[t]{2}{*}{$\mathbf{X}^{2}, \mathrm{p}$-value } \\
\hline & & & & & \\
\hline \multirow[t]{4}{*}{ Age } & $18-29$ & $78(56.9)$ & $97(67.8)$ & $175(62.5)$ & $5.283,0.152$ \\
\hline & $30-39$ & $47(34.3)$ & $36(25.2)$ & $83(29.6)$ & \\
\hline & $40-49$ & II (8.0) & $7(4.9)$ & $18(6.4)$ & \\
\hline & $\geq 50$ & I (0.7) & $3(2.1)$ & $4(1.4)$ & \\
\hline \multirow[t]{2}{*}{ Sex } & Male & $89(54.9)$ & $73(45.1)$ & $162(57.9)$ & $2.300,0.129$ \\
\hline & Female & $54(45.8)$ & $64(54.2)$ & $118(42.1)$ & \\
\hline \multirow[t]{5}{*}{ Religion } & Orthodox & $104(75.9)$ & $102(7 \mid .3)$ & $206(73.6)$ & $4.865,0.301$ \\
\hline & Muslim & $13(9.5)$ & $12(8.4)$ & $25(8.9)$ & \\
\hline & Catholic & $3(2.2)$ & I (0.7) & $4(1.4)$ & \\
\hline & Protestant & $13(9.5)$ & $25(17.5)$ & $38(13.6)$ & \\
\hline & Others & $4(2.9)$ & $3(2.1)$ & $7(2.5)$ & \\
\hline \multirow[t]{2}{*}{ Educational level } & Diploma & $47(34.3)$ & $4 \mathrm{I}(28.7)$ & $88(31.4)$ & $1.031,0.310$ \\
\hline & Degree and above & $90(65.7)$ & $102(7 \mid .3)$ & $192(68.6)$ & \\
\hline \multirow[t]{3}{*}{ Work experience } & $<5$ & $74(54.0)$ & $96(67.6)$ & $170(60.9)$ & $7.845,0.020$ \\
\hline & $5-10$ & $41(29.9)$ & $23(16.2)$ & $64(29.2)$ & \\
\hline & $>10$ & $22(16.1)$ & $23(16.2)$ & $45(16.1)$ & \\
\hline \multirow[t]{3}{*}{ Monthly income } & $<5000$ & $59(43.1)$ & $69(48.3)$ & $128(45.7)$ & $1.996,0.369$ \\
\hline & 5000-9999 & $75(54.7)$ & $68(47.6)$ & I43 (5I.I) & \\
\hline & $\geq 10,000$ & $3(2.2)$ & $6(4.2)$ & $9(3.2)$ & \\
\hline \multirow[t]{5}{*}{ Profession } & Pharmacy & II (8.0) & 17 (II.9) & $28(10.0)$ & $6.211,0.184$ \\
\hline & Nurse & $66(48.2)$ & $76(53.1)$ & $142(50.7)$ & \\
\hline & Laboratory & $22(16.1)$ & II (7.7) & $33(11.8)$ & \\
\hline & Midwifery & $23(16.8)$ & $20(14.0)$ & $43(15.4)$ & \\
\hline & MD and other Masters & $15(10.9)$ & $19(13.3)$ & $34(12.1)$ & \\
\hline \multirow[t]{5}{*}{ Ward } & Medical & $32(23.4)$ & $28(19.6)$ & $60(21.4)$ & $5.618,0.230$ \\
\hline & Surgical & $26(19.0)$ & $24(16.8)$ & $50(17.9)$ & \\
\hline & Pediatrics & $12(8.8)$ & 17 (II.9) & $29(10.4)$ & \\
\hline & Oby/gyn & $25(18.2)$ & $16(12.1)$ & $4 I(14.6)$ & \\
\hline & OPD and NICU & $42(30.7)$ & $58(40.6)$ & $100(35.7)$ & \\
\hline \multirow[t]{4}{*}{ Marital status } & Single & $54(39.4)$ & $77(53.8)$ & $|3|(46.8)$ & $7.874,0.049$ \\
\hline & Divorced & $8(5.8)$ & $4(2.8)$ & $12(4.3)$ & \\
\hline & Windowed & $6(4.4)$ & $2(1.4)$ & $8(2.9)$ & \\
\hline & Married & $69(50.4)$ & $60(42.0)$ & $129(46.1)$ & \\
\hline \multirow[t]{3}{*}{ Family size } & 1 & $62(45.3)$ & $69(48.3)$ & $|3|(46.8)$ & $1.760,0.415$ \\
\hline & 2 & $42(30.7)$ & $34(23.8)$ & (76 (27.1) & \\
\hline & $\geq 3$ & $33(24.1)$ & $40(28.0)$ & $73(26.1)$ & \\
\hline
\end{tabular}

present in the room, the possibility of isolating suspected cases separately, and availability of engineering control to shield health care workers from clients.
Operational Definition Occupational Health and Safety

According to WHO (1995), occupational safety and health can be defined as a multidisciplinary activity aiming at Protection 
Table 2 Availability of Personnel Protective Equipment at Hospitals During COVID-I9 Pandemics in North Showa Zone, Oromia Regional State, Ethiopia, 2020

\begin{tabular}{|c|c|c|c|c|c|}
\hline \multirow[t]{3}{*}{ Variables } & \multirow[t]{3}{*}{ Category } & \multicolumn{4}{|c|}{ Occupational Health and Safety } \\
\hline & & \multirow{2}{*}{$\begin{array}{c}\text { Unfavorable } \\
\begin{array}{c}\text { Frequency } \\
\text { (\%) }\end{array}\end{array}$} & \multirow{2}{*}{$\begin{array}{c}\text { Favorable } \\
\begin{array}{c}\text { Frequency } \\
(\%)\end{array}\end{array}$} & \multirow{2}{*}{$\begin{array}{c}\text { Total } \\
\text { Frequency } \\
\text { (\%) }\end{array}$} & \multirow[t]{2}{*}{$\mathbf{X}^{2}, \mathrm{p}$-value } \\
\hline & & & & & \\
\hline Do you have appropriate personnel protective equipment? & $\begin{array}{l}\text { No } \\
\text { Yes }\end{array}$ & $\begin{array}{l}69(50.4) \\
68(49.6)\end{array}$ & $\begin{array}{l}44(30.8) \\
99(69.2)\end{array}$ & $\begin{array}{l}113(40.4) \\
167(59.6)\end{array}$ & II.162,0.001 \\
\hline Do you have a face mask to wear during serving the client? & $\begin{array}{l}\text { No } \\
\text { Yes }\end{array}$ & $\begin{array}{l}40(29.2) \\
97(70.8)\end{array}$ & $\begin{array}{l}26(18.2) \\
I I 7(8 I .8)\end{array}$ & $\begin{array}{l}66(23.6) \\
214(76.4)\end{array}$ & $4.712,0.030$ \\
\hline Do you have enough gloves in your room? & $\begin{array}{l}\text { No } \\
\text { Yes }\end{array}$ & $\begin{array}{l}80(58.4) \\
57(41.6)\end{array}$ & $\begin{array}{l}55(38.5) \\
88(61.5)\end{array}$ & $\begin{array}{l}\text { I35 (48.2) } \\
\text { I } 45(5 \mid .8)\end{array}$ & $11.134,0.001$ \\
\hline Do you have eye/face protection (eg, goggles, face shield) & $\begin{array}{l}\text { No } \\
\text { Yes }\end{array}$ & $\begin{array}{l}94(68.6) \\
43(31.4)\end{array}$ & $\begin{array}{l}76(53.1) \\
67(46.9)\end{array}$ & $\begin{array}{l}\text { I70 (60.7) } \\
\text { IIO }(39.3)\end{array}$ & $7.017,0.008$ \\
\hline Do you have disinfectants around your working area? & $\begin{array}{l}\text { No } \\
\text { Yes }\end{array}$ & $\begin{array}{l}65(47.4) \\
72(52.6)\end{array}$ & $\begin{array}{l}43(30.1) \\
100(69.9)\end{array}$ & $\begin{array}{l}108(38.6) \\
\text { I72 (6I.4) }\end{array}$ & $8.915,0.003$ \\
\hline Do you have antiseptics around your working area? & $\begin{array}{l}\text { No } \\
\text { Yes }\end{array}$ & $\begin{array}{l}68(49.6) \\
69(50.4)\end{array}$ & $\begin{array}{l}33(23.1) \\
110(76.9)\end{array}$ & $\begin{array}{l}\text { I0I (36.I) } \\
\text { I79 (63.9) }\end{array}$ & $2 \mathrm{I} .40 \mathrm{I},<0.00 \mathrm{I}$ \\
\hline $\begin{array}{l}\text { Do you have an accessible handwashing facility in your } \\
\text { working room? }\end{array}$ & $\begin{array}{l}\text { No } \\
\text { Yes }\end{array}$ & $\begin{array}{l}67(48.9) \\
70(51.1)\end{array}$ & $\begin{array}{l}37(25.9) \\
106(74.1)\end{array}$ & $\begin{array}{l}104(37.1) \\
176(62.9)\end{array}$ & $15.896,<0.00 \mid$ \\
\hline Do you have soap or bleach in your room? & $\begin{array}{l}\text { No } \\
\text { Yes }\end{array}$ & $\begin{array}{l}85(62.0) \\
52(38.0)\end{array}$ & $\begin{array}{l}41(28.7) \\
102(71.3)\end{array}$ & $\begin{array}{l}126(45.0) \\
126(55.0)\end{array}$ & $31.485,<0.00 \mathrm{I}$ \\
\hline
\end{tabular}

and promotion of the health of workers by eliminating occupational factors and conditions hazardous to health and safety at work, Enhancement of physical, mental, and social wellbeing of workers and support for the development and maintenance of their working capacity, as well as professional and social development at work, Development and promotion of sustainable work environments and work organizations.

In this study, participant's OHS issues were assessed with 19 questions each weighs equal value. The maximum score for each participant was 19 and the minimum score will be 0 points. At last, the scores of each question were categorized into two levels of OHS:

- Favorable OHS: a score of above the mean

- Unfavorable OHS: a score of mean and below OHS

\section{Data Processing and Analysis}

After data collection, data were checked for completeness and coded, cleaned, and entered into EPI data, and transported to SPSS version 23 for data cleaning and analysis. Descriptive statistics such as tables and proportions were used to present the data. Bivariate and multivariate logistic regression analyses were done to see the association between dependent and independent variables.

\section{Results}

\section{Socio-Demographic Characteristics of Respondents}

A total of 280 study participants participated in the study with a $92.7 \%$ response rate. Of which $57.9 \%$ were males while $42.1 \%$ of study participants were females. The mean age of study participants was 29.60 \pm 5.86 . Regards to the profession of study participants half of the study participants $50.7 \%$ were nurses (Table 1).

\section{Availability of Personnel Protective Equipment}

Regards to availability of personnel protective equipment from these hospitals during COVID-19 Pandemics, 48.2\% of respondents lack gloves or they had a shortage of gloves, incase $45 \%$ of study participants had no soap or 
Table 3 Engineering and Administrative Control of Hospitals During COVID-19 Pandemics in North Showa Zone, Oromia Regional State, Ethiopia, 2020

\begin{tabular}{|c|c|c|c|c|c|}
\hline \multirow[t]{3}{*}{ Variables } & \multirow[t]{3}{*}{ Category } & \multicolumn{4}{|c|}{ Occupational Health and Safety } \\
\hline & & \multirow{2}{*}{\begin{tabular}{|c|} 
Unfavorable \\
$\begin{array}{c}\text { Frequency } \\
\text { (\%) }\end{array}$
\end{tabular}} & \multirow{2}{*}{$\begin{array}{c}\text { Favorable } \\
\begin{array}{c}\text { Frequency } \\
\text { (\%) }\end{array}\end{array}$} & \multirow{2}{*}{$\begin{array}{c}\text { Total } \\
\begin{array}{c}\text { Frequency } \\
(\%)\end{array}\end{array}$} & \multirow[t]{2}{*}{$x^{2}, p$-value } \\
\hline & & & & & \\
\hline $\begin{array}{l}\text { Do you restrict the number of personnel entering the room } \\
\text { of a patient? }\end{array}$ & $\begin{array}{l}\text { No } \\
\text { Yes }\end{array}$ & $\begin{array}{l}73(47.1) \\
70(56)\end{array}$ & $\begin{array}{l}82(52.9) \\
55(44)\end{array}$ & $\begin{array}{l}155(55.4) \\
125(44.6)\end{array}$ & $2.195,0.138$ \\
\hline $\begin{array}{l}\text { Do you minimize the number of staff present when } \\
\text { performing aerosol-generating procedures? }\end{array}$ & $\begin{array}{l}\text { No } \\
\text { Yes }\end{array}$ & $\begin{array}{l}77(46.1) \\
66(58.4)\end{array}$ & $\begin{array}{l}90(53.9) \\
47(41.6)\end{array}$ & $\begin{array}{l}167(59.6) \\
113(40.4)\end{array}$ & $4.080,00.043$ \\
\hline $\begin{array}{l}\text { Is it possible isolating suspected cases separately to help } \\
\text { prevent transmission }\end{array}$ & $\begin{array}{l}\text { No } \\
\text { Yes }\end{array}$ & $\begin{array}{l}40(32) \\
103(66.5)\end{array}$ & $\begin{array}{l}85(68) \\
52(33.5)\end{array}$ & $\begin{array}{l}125(44.6) \\
155(55.4)\end{array}$ & $32.867,<0.001$ \\
\hline $\begin{array}{l}\text { Is their engineering controls to shield healthcare workers } \\
\text { from patients, especially at triage areas }\end{array}$ & $\begin{array}{l}\text { No } \\
\text { Yes }\end{array}$ & $\begin{array}{l}65(39.4) \\
78(67.8)\end{array}$ & $\begin{array}{l}100(60.6) \\
37(32.2)\end{array}$ & $\begin{array}{l}165(58.9) \\
115(4 I . I)\end{array}$ & $21.923,<0.001$ \\
\hline $\begin{array}{l}\text { Is there infection prevention and control program standards } \\
\text { and policies in your organization? }\end{array}$ & $\begin{array}{l}\text { No } \\
\text { Yes }\end{array}$ & $\begin{array}{l}34(32.4) \\
109(62.3)\end{array}$ & $\begin{array}{l}71(67.6) \\
66(37.7)\end{array}$ & $\begin{array}{l}105(37.5) \\
175(62.5)\end{array}$ & $23.486,<0.001$ \\
\hline $\begin{array}{l}\text { Does your organization have a policy and procedure for } \\
\text { COVID-19 prevention? }\end{array}$ & $\begin{array}{l}\text { No } \\
\text { Yes }\end{array}$ & $\begin{array}{l}37(32.7) \\
106(63.5)\end{array}$ & $\begin{array}{l}76(67.3) \\
61(36.5)\end{array}$ & $\begin{array}{l}113(40.4) \\
167(59.6)\end{array}$ & $25.469,<0.001$ \\
\hline $\begin{array}{l}\text { Does the facility's policy include notifying if there are clusters } \\
\text { of respiratory illness of COVID }\end{array}$ & $\begin{array}{l}\text { Yes } \\
\text { No }\end{array}$ & $\begin{array}{l}40(35.1) \\
103(62)\end{array}$ & $\begin{array}{l}74(64.9) \\
63(38)\end{array}$ & $\begin{array}{l}114(40.7) \\
166(59.3)\end{array}$ & $|9.659,<0.00|$ \\
\hline
\end{tabular}

bleach in their room. Contemporarily, $76.4 \%$ of study participants respond as they had face mask to wear during serving the client (Table 2).

\section{Engineering and administrative control}

The majority of the participants $55.4 \%$ were not restricted the number of personnel entering into the patient's room. When we assess the number of staff present during the aerosol-generating procedure, $167(59.6 \%)$ respondents respond as they had not minimized their staff. The largest proportion of the participants with a total number of 165 $(58.9 \%)$ were not had engineering control (Table 3).

\section{Occupational Health and Safety of Health Professionals During COVID-19 \\ Pandemics}

Occupational health and safety of health professionals are mandatory mainly at this time since there was a highly contagious COVID-19 pandemic worldwide, to save the life of health professionals and other individuals in the community. Here is $48.9 \%$ of health professionals had unfavorable occupational health and safety, whereas $51.1 \%$ had favorable occupational health and safety (Table 4).

\section{Factors Associated with Occupational Health and Safety Among Health Professionals}

The effects of different independent variables were tested for the presence of association with occupational health and safety of health professionals using bivariate logistic regression analysis. Variables having P-values $<0.2$ in the bivariate logistic regression analysis were included in multivariable analysis.

At this step, sex of respondents, availability of appropriate PPE, availability of face masks, availability of enough gloves, availability of eye protection, availability of disinfectants around their working area, availability of antiseptics, availability of accessible handwashing facility in their room, availability of soap or bleach, restrict the number of personnel entering the room of a patient, minimizing the number of staff present when performing activities, isolating suspected 
Table 4 Safe Working Practices of Health Professionals During COVID-19 Pandemics at Hospitals in North Showa Zone, Oromia Regional State, Ethiopia, 2020

\begin{tabular}{|c|c|c|c|}
\hline \multirow[t]{3}{*}{ Variables } & \multicolumn{3}{|c|}{ Category } \\
\hline & No & Yes & $x^{2}$ \\
\hline & $\begin{array}{c}\text { Frequency } \\
\text { (\%) }\end{array}$ & $\begin{array}{c}\text { Frequency } \\
\text { (\%) }\end{array}$ & P-value \\
\hline $\begin{array}{l}\text { Do you wear gloves when you } \\
\text { have contact with patients? }\end{array}$ & 40 (14.3\%) & $240(85.7 \%)$ & $\begin{array}{l}21.048 \\
<0.001\end{array}$ \\
\hline $\begin{array}{l}\text { Do you wear a proper face } \\
\text { mask when you are serving the } \\
\text { client? }\end{array}$ & 91 (32.5\%) & $189(67.5 \%)$ & $\begin{array}{l}13.651 \\
<0.001\end{array}$ \\
\hline $\begin{array}{l}\text { Do you clean and disinfect } \\
\text { reusable instruments after } \\
\text { each client? }\end{array}$ & $66(23.6 \%)$ & $214(76.4 \%)$ & $\begin{array}{l}37.382 \\
<0.001\end{array}$ \\
\hline $\begin{array}{l}\text { Do you wash your hand } \\
\text { appropriately with water } \\
\text { before wearing PPE? }\end{array}$ & 89 (31.8\%) & 191 (68.2\%) & $\begin{array}{l}57.183 \\
<0.001\end{array}$ \\
\hline $\begin{array}{l}\text { Do you perform hand hygiene } \\
\text { before contact with the } \\
\text { patient? (even if gloves are } \\
\text { used) }\end{array}$ & $8 \mathrm{l}(28.9 \%)$ & 199 (71.1\%) & $\begin{array}{l}64.107 \\
<0.001\end{array}$ \\
\hline $\begin{array}{l}\text { Do you perform hand hygiene } \\
\text { after contact with the patient? } \\
\text { (even if gloves are used) }\end{array}$ & $8 \mathrm{l}(28.9 \%)$ & 199 (71.1\%) & $\begin{array}{l}77.399 \\
<0.001\end{array}$ \\
\hline $\begin{array}{l}\text { Do you perform hand hygiene } \\
\text { after removing PPE (eg, gloves, } \\
\text { gown, and facemask)? }\end{array}$ & 72 (25.7\%) & $208(74.3 \%)$ & $\begin{array}{l}80.355 \\
<0.001\end{array}$ \\
\hline $\begin{array}{l}\text { Do you use an alcohol-based } \\
\text { hand rub after you serve each } \\
\text { client? }\end{array}$ & 76 (27.1\%) & 204 (72.9\%) & $\begin{array}{l}60.005 \\
<0.001\end{array}$ \\
\hline $\begin{array}{l}\text { Do you change gloves when } \\
\text { indicated and performed hand } \\
\text { hygiene? }\end{array}$ & 66 (23.6\%) & $214(76.4 \%)$ & $\begin{array}{l}52.428 \\
<0.001\end{array}$ \\
\hline $\begin{array}{l}\text { Removed and discarded PPE } \\
\text { after resident care and prior to } \\
\text { leaving room appropriately }\end{array}$ & 55 (19.6\%) & 225 (80.4\%) & $\begin{array}{l}44.181 \\
<0.001\end{array}$ \\
\hline $\begin{array}{l}\text { Do you wash your hands } \\
\text { before and after performing } \\
\text { a procedure? }\end{array}$ & $80(28.6 \%)$ & 200 (71.4\%) & $\begin{array}{l}71.074 \\
<0.001\end{array}$ \\
\hline $\begin{array}{l}\text { Do you perform routine } \\
\text { cleaning and disinfection } \\
\text { procedures? }\end{array}$ & 75 (26.8\%) & 205 (73.2\%) & $\begin{array}{l}46.662 \\
<0.001\end{array}$ \\
\hline $\begin{array}{l}\text { Do you differentiate clean } \\
\text { areas where PPE is put on from } \\
\text { potentially contaminated areas } \\
\text { where PPE is removed? }\end{array}$ & 94 (33.6\%) & $186(66.4 \%)$ & $\begin{array}{l}74.117 \\
<0.001\end{array}$ \\
\hline
\end{tabular}

(Continued)
Table 4 (Continued)

\begin{tabular}{|c|c|c|c|}
\hline \multirow[t]{3}{*}{ Variables } & \multicolumn{3}{|c|}{ Category } \\
\hline & \multirow{2}{*}{$\begin{array}{c}\text { No } \\
\text { Frequency } \\
\text { (\%) }\end{array}$} & \multirow{2}{*}{$\begin{array}{c}\text { Yes } \\
\text { Frequency } \\
\text { (\%) }\end{array}$} & \multirow{2}{*}{$\begin{array}{c}X^{2}, \\
p \text {-value }\end{array}$} \\
\hline & & & \\
\hline $\begin{array}{l}\text { Do you handle waste and } \\
\text { other potentially infectious } \\
\text { materials properly? }\end{array}$ & 67 (23.9\%) & $213(76.1 \%)$ & $\begin{array}{l}42.326 \\
<0.001\end{array}$ \\
\hline $\begin{array}{l}\text { Do you avoid touching your } \\
\text { faces, eyes, noses, and mouth } \\
\text { after you have thoroughly } \\
\text { washed your hands upon } \\
\text { completing work and/or } \\
\text { removing PPE? }\end{array}$ & 92 (32.9\%) & 188 (67.1\%) & $\begin{array}{l}50.739 \\
<0.001\end{array}$ \\
\hline $\begin{array}{l}\text { Have you been tested for } \\
\text { COVID-19? }\end{array}$ & 172 (6I.4\%) & $108(38.6 \%)$ & $0.205,0.651$ \\
\hline $\begin{array}{l}\text { Do you have taken any } \\
\text { orientation, training or } \\
\text { education on COVID-19 }\end{array}$ & I 30 (46.4\%) & I 50 (53.6\%) & $\begin{array}{l}8.825 \\
0.003\end{array}$ \\
\hline $\begin{array}{l}\text { Do you maintain social } \\
\text { distance during the COVID-19 } \\
\text { outbreak? }\end{array}$ & $86(30.7 \%)$ & 194 (69.3\%) & $\begin{array}{l}32.274 \\
<0.001\end{array}$ \\
\hline $\begin{array}{l}\text { Do you avoid crowded places } \\
\text { like workshop places, bus, and } \\
\text { train stations, bank }\end{array}$ & 113 (40.4\%) & 167 (59.6\%) & $\begin{array}{l}16.581 \\
<0.001\end{array}$ \\
\hline \multirow{2}{*}{$\begin{array}{l}\text { Total occupational health and } \\
\text { safety }\end{array}$} & Favorable & I37 (48.9) & \\
\hline & Unfavorable & I43 (5I.I) & \\
\hline
\end{tabular}

cases separately, availability of engineering controls to shield healthcare workers from patients, availability of functional infection prevention and control program standards and policy, availability of policy and procedure for COVID-19 prevention, notify if there are clusters of respiratory illness or cases of COVID-19, knowledge and attitude of health professionals had a statistically significant association with occupational health and safety of health professionals at $\mathrm{P}<0.20$.

Finally, multivariable logistic regression at a P-value less than 0.05 with the forward method was used to assess factors associated with occupational health and safety of health professionals, after checking the HosmerLemeshow goodness of fit test (0.783)

Health professionals who had soap and bleach in his/ her room were 2.5 times more likely to be occupational 
health safe than those who had not soap and bleach ( $\mathrm{AOR}=2.50,95 \% \mathrm{CI}: 1.439,4.356)$.

Health professionals who can isolate the suspected COVID-19 clients were almost 3 times occupationally health safe than the counterpart ( $\mathrm{AOR}=2.525,95 \% \mathrm{CI}: 1.690,5.062)$.

When there were infections prevention and control program standards and policy in hospitals the occupational health safety of health professionals increased by 2.33 than those who had not IPC policy $(\mathrm{AOR}=2.329,95 \% \mathrm{CI}$ : 1.325 , 4.092). Additionally, health professionals who had policies and procedures to prevent COVID-19 were 2.43 times to have had favorable occupational health and safety than the counterpart $(\mathrm{AOR}=2.427,95 \% \mathrm{CI}: 1.389,4.240)$ (Table 5).

\section{Discussion}

At this time when the world is with COVID-19 pandemics, scientific investigations on health professionals' occupational safety are necessary to take appropriate measures and to save their life from this fatal pandemic. Therefore, the study was conducted to assess occupational health safety of health professionals and associated factors during COVID-19 pandemic at North Showa Zone, Oromia Regional State, Ethiopia.

This study revealed that only half of study participants $51.1 \%(n=143)(95 \%$ CI: 45.0-56.8) of health professionals had favorable occupational health and safety, while $48.9 \%$ $(n=137)(95 \%$ CI: 43.2, 55.0) health professionals had unfavorable occupational safety and health. This finding is slightly higher than the previous study conducted in Trabzon, Turkey. ${ }^{15}$ This difference might be due to variations in the study setting, socio-cultural difference and there are some considerations to prevent COVID-19 infections of health professionals currently. Even if occupational safety of health professionals showed that improvement when compared with studies conducted before COVID - 19 pandemics, $48.9 \%$ unfavorable OHS might affect the life of health professionals, the health of the clients, and the outcome of health service at large. Therefore, the ministry of health, the government, and hospital administrations shall be given great attention to the OHS of health professionals.

In addition to assessing the level of OHS of health professionals, this study also predicts various predictors of OHS among health professionals. In this way, the Availability of soap and bleach, the possibility of isolating suspected cases separately, availability of infections prevention and control program standards and policy, and availability of policy and procedure to prevent COVID-19 had a statistically significant association with OHS in this study.
Availability of soap and bleach and the possibility of isolating suspected cases separately were novel or new variables which were showed statistically significant association with OHS, On the other hand being a male healthcare provider, having work experience of and having a poor attitude towards COVID-19 were had statistically significant association on other studies but not on this study. ${ }^{16}$

This study revealed that lack of soap and bleach in health professionals' rooms can decrease health professionals' occupational safety and health $(\mathrm{AOR}=2.50,95 \% \mathrm{CI}: 1.439$, 4.356). This could be described as shortages of soap and bleach in health professionals "rooms that could influence the handwashing practice of health professionals" before and after patient contact. Hand washing for 20 seconds was one of the WHO recommendations to prevent COVID-19 pandemics. Therefore, lack of handwashing affected occupational safety and health of health professionals'.

The possibility of isolating suspected cases separately was one of the predictor variables for occupational safety and health of health professionals. Health professionals who can isolate the suspected COVID-19 clients were almost 3 times occupationally health safe than the counterpart $(\mathrm{AOR}=2.525,95 \% \mathrm{CI}: 1.690,5.062)$. This might indicate that health professionals' who can isolate suspected cases separately from other clients and staff tended to decrease the spread of COVID-19 by avoiding direct contact of COVID19 infected individuals from non-infected ones.

When there were infections prevention and control program standards and policy in hospitals the occupational safety and health of health professionals increased by 2.33 $(\mathrm{AOR}=2.329$, 95\% CI: 1.325, 4.092). Because of the availability of these standards and policies used to enhance health professionals' to implement COVID - 19 prevention and control methods like wearing a mask, wearing gloves appropriately, hand washing, physical distancing, and other precaution from other injuries. This finding was supported by another study. ${ }^{17}$

The availability of policy and procedure to prevent COVID-19 had a statistical significant association with both OHS. Health professionals' who respond as there were policy and procedure to prevent COVID-19 were 2.43 times to have had good occupational safety and health than the counterpart $(\mathrm{AOR}=2.427,95 \% \mathrm{CI}: 1.389,4.240)$. The possible reason for this association could be the availability of specific policy and procedure to the prevention of COVID-19 can contribute to OHS directly for implementing prevention and control methods or indirectly by increasing knowledge, attitude, and awareness of health 
Table 5 Bivariable and Multivariable Analysis of Factors Associated with Occupational Health and Safety Among Health Professionals at Hospitals in North Showa Zone, Oromia Regional State, Ethiopia, 2020

\begin{tabular}{|c|c|c|c|c|c|}
\hline \multirow[t]{2}{*}{ Characteristics } & \multirow[t]{2}{*}{ Category } & \multicolumn{2}{|c|}{ Occupational Health and Safety } & \multirow[t]{2}{*}{ COR $(95 \% \mathrm{Cl})$} & \multirow[t]{2}{*}{ AOR $(95 \% \mathrm{Cl})$} \\
\hline & & Unfavorable n (\%) & Favorable $\mathbf{n}(\%)$ & & \\
\hline Sex & $\begin{array}{l}\text { Male } \\
\text { Female }\end{array}$ & $\begin{array}{l}73(45.1) \\
64(54.2)\end{array}$ & $\begin{array}{l}89(54.9) \\
54(45.8)\end{array}$ & $\begin{array}{l}\text { I } \\
\text { I.445 } \\
(0.897-2.327)\end{array}$ & - \\
\hline Availability appropriate PPE & $\begin{array}{l}\text { No } \\
\text { Yes }\end{array}$ & $\begin{array}{l}69(61.0) \\
68(40.7)\end{array}$ & $\begin{array}{l}44(38.9) \\
99(59.3)\end{array}$ & $\begin{array}{l}1 \\
2.283 \\
(1.401-3.720)\end{array}$ & - \\
\hline Availability of face mask & $\begin{array}{l}\text { No } \\
\text { Yes }\end{array}$ & $\begin{array}{l}40(60.6) \\
97(45.3)\end{array}$ & $\begin{array}{l}26(39.4) \\
117(54.7)\end{array}$ & $\begin{array}{l}I \\
I .856 \\
(1.058-3.256)\end{array}$ & - \\
\hline Availability of enough glove & $\begin{array}{l}\text { No } \\
\text { Yes }\end{array}$ & $\begin{array}{l}80(59.3) \\
57(39.3)\end{array}$ & $\begin{array}{l}55(40.7) \\
88(60.7)\end{array}$ & $\begin{array}{l}1 \\
2.246 \\
(1.392-3.623)\end{array}$ & - \\
\hline Availability of eye/face protection & $\begin{array}{l}\text { No } \\
\text { Yes }\end{array}$ & $\begin{array}{l}94(55.3) \\
43(39.1)\end{array}$ & $\begin{array}{l}76(44.7) \\
67) 60.9)\end{array}$ & $\begin{array}{l}1 \\
1.927 \\
(1.183-3.139)\end{array}$ & - \\
\hline Availability of disinfectants & $\begin{array}{l}\text { No } \\
\text { Yes }\end{array}$ & $\begin{array}{l}65(60.2) \\
72(41.9)\end{array}$ & $\begin{array}{l}43(39.8) \\
100(58.1)\end{array}$ & $\begin{array}{l}1 \\
2.099 \\
(1.286-3.427)\end{array}$ & - \\
\hline Availability of antiseptics & $\begin{array}{l}\text { No } \\
\text { Yes }\end{array}$ & $\begin{array}{l}68(67.3) \\
69(38.5\end{array}$ & $\begin{array}{l}33(32.7) \\
110(6 I .5)\end{array}$ & $\begin{array}{l}1 \\
3.285 \\
(1.966-5.489)\end{array}$ & - \\
\hline Accessibility of handwashing facilities & $\begin{array}{l}\text { No } \\
\text { Yes }\end{array}$ & $\begin{array}{l}67(64.4) \\
70(39.8)\end{array}$ & $\begin{array}{l}37(35.6) \\
106(60.2)\end{array}$ & $\begin{array}{l}1 \\
2.742 \\
(1.659-4.531)\end{array}$ & - \\
\hline Availability of soap and bleach & $\begin{array}{l}\text { No } \\
\text { Yes }\end{array}$ & $\begin{array}{l}85(67.5) \\
52(33.8\end{array}$ & $\begin{array}{l}41(32.5) \\
102(66.2)\end{array}$ & $\begin{array}{l}\text { I } \\
4.067 \\
(2.465-6.708)\end{array}$ & $\begin{array}{l}\text { I } \\
2.503 \\
(1.439-4.356)^{* *}\end{array}$ \\
\hline Restriction of persons entering the room & $\begin{array}{l}\text { No } \\
\text { Yes }\end{array}$ & $\begin{array}{l}82(52.9) \\
55(44)\end{array}$ & $\begin{array}{l}73(47.1) \\
70(56)\end{array}$ & $\begin{array}{l}\text { I } \\
\text { I.340 } \\
(0.890-2.295)\end{array}$ & - \\
\hline $\begin{array}{l}\text { Limit persons while doing aerosol-generating } \\
\text { procedures }\end{array}$ & $\begin{array}{l}\text { No } \\
\text { Yes }\end{array}$ & $\begin{array}{l}90(53.9) \\
47(41.6)\end{array}$ & $\begin{array}{l}77(46.1) \\
66(58.4)\end{array}$ & $\begin{array}{l}\text { I } \\
1.641 \\
(1.013-2.658)\end{array}$ & - \\
\hline $\begin{array}{l}\text { Possibility of isolating suspected COVID-19 } \\
\text { cases }\end{array}$ & $\begin{array}{l}\text { No } \\
\text { Yes }\end{array}$ & $\begin{array}{l}85(68) \\
52(33.5)\end{array}$ & $\begin{array}{l}40(32) \\
103(66.5)\end{array}$ & $\begin{array}{l}\text { I } \\
4.209 \\
(2.547-6.956)\end{array}$ & $\begin{array}{l}\text { I } \\
2.925 \\
(1.690-5.062)^{* * *}\end{array}$ \\
\hline $\begin{array}{l}\text { Presence of engineering control to shield HCW } \\
\text { from Pts. }\end{array}$ & $\begin{array}{l}\text { No } \\
\text { Yes }\end{array}$ & $\begin{array}{l}100(60.6) \\
37(32.2)\end{array}$ & $\begin{array}{l}65(39.4) \\
78(67.8)\end{array}$ & $\begin{array}{l}\text { I } \\
3.243 \\
(1.966-5.350)\end{array}$ & - \\
\hline
\end{tabular}

(Continued) 
Table 5 (Continued).

\begin{tabular}{|c|c|c|c|c|c|}
\hline \multirow[t]{2}{*}{ Characteristics } & \multirow[t]{2}{*}{ Category } & \multicolumn{2}{|c|}{ Occupational Health and Safety } & \multirow[t]{2}{*}{$\operatorname{COR}(95 \% \mathrm{Cl})$} & \multirow[t]{2}{*}{ AOR $(95 \% \mathrm{Cl})$} \\
\hline & & Unfavorable n (\%) & Favorable $\mathrm{n}(\%)$ & & \\
\hline Presence of IP \& control program and policy & $\begin{array}{l}\text { No } \\
\text { Yes }\end{array}$ & $\begin{array}{l}71(67.6) \\
66(37.7)\end{array}$ & $\begin{array}{l}34(32.4) \\
109(62.3)\end{array}$ & $\begin{array}{l}\text { I } \\
3.449 \\
(2.070-5.746)\end{array}$ & $\begin{array}{l}\text { I } \\
2.329 \\
(1.325-4.092)^{* *}\end{array}$ \\
\hline Policy \& protocols for COVI-19 prevention & $\begin{array}{l}\text { No } \\
\text { Yes }\end{array}$ & $\begin{array}{l}76(67.3) \\
6 I(36.5)\end{array}$ & $\begin{array}{l}37(32.7) \\
106(63.5)\end{array}$ & $\begin{array}{l}\text { I } \\
3.569 \\
(2.157-5.906)\end{array}$ & $\begin{array}{l}\text { I } \\
2.427 \\
(1.389-4.240)^{* *}\end{array}$ \\
\hline $\begin{array}{l}\text { Does facility' policy and procedure includes } \\
\text { when to notify }\end{array}$ & $\begin{array}{l}\text { No } \\
\text { Yes }\end{array}$ & $\begin{array}{l}74(64.9) \\
63(38)\end{array}$ & $\begin{array}{l}40(35.1) \\
103(62)\end{array}$ & $\begin{array}{l}1 \\
3.025 \\
(1.841-4.98)\end{array}$ & - \\
\hline
\end{tabular}

Note: **Statistically significant at $\mathrm{P}<0.01, * * *$ statistically significant at $\mathrm{p}<0.001$.

professionals'. This variable also showed a similar association in the study conducted in Aksum. ${ }^{17}$

\section{Strength of the Study}

The main strength of this study was we have addressed all hospitals in the study area during the sampling procedure, which increases the representatives of the sample to the general population.

\section{Limitation of the Study}

The main limitation of this study was the discussion part of this study did not synthesize with other research works since a limited study on OHS during COVID-19 pandemics in other areas.

\section{Conclusions}

This study achieves that the safety of health professionals was at risk since their OHS and was low. Among the different potential factors, Availability of soap and bleach, the possibility of isolating suspected cases separately, availability of functional infections prevention and control program standards and policy, and availability of policy and procedure to prevent COVID-19 had a statistically significant association with OHS.

\section{Abbreviations}

COVID-19, Coronavirus Diseases 2019; CDC, Communicable Disease and Control; HCW, Health Care Workers; ILO, International Labour Organization; IPC, Infection Prevention and Control; IPCP, Interprofessional
Collaborative Practice; MERS, the Middle East Respiratory syndrome; NIOSH, National Institute for Occupational Safety and Health; OHS, Occupational Health and Safety; PPE, Personal Protective Equipment; SARS, Severe Acute Respiratory Syndrome; WASH, Water, Sanitation, and Hygiene; WHO, World Health Organization.

\section{Ethical Considerations}

Ethical clearance was obtained from Salale University's ethical review board (permit number: SLUERC 229/20/2020). Letters of support were received from this university. The purpose of the study was explained to the hospital managers and the study participants. The study was conducted according to the Declaration of Helsinki. Before collecting the data, written informed consent was secured from each participant. All information obtained from the Hospital \& respondents was kept confidential.

\section{Acknowledgment}

We would like to acknowledge Salale University, College of Health Sciences, and all individuals who participated in the success of this study.

\section{Funding}

Funding was obtained for this study from Salale University.

\section{Disclosure}

The authors declare that they have no conflicts of interest. 


\section{References}

1. Wang HJ, Du SH, Yue X, Chen CX. Review and prospect of pathological features of coronavirus diseases. Fa Yi Xue Zahi. 2020;26 (1):16-20.

2. Singhal T. A review of coronavirus disease-2019 (COVID-19). Indian J Pediatr. 2020;87 (4):281-286. doi:10.1007/s12098-020-03263-6

3. Worldometers, Available from: https://www.worldometers.info/. Accessed March 12, 2021.

4. Foruem WE. Why sub-Saharan Africa needs a unique response to COVI-19. Switzerland: Worled Economic Foruem Cologny; 2020.

5. ECDC. Infection prevention and control and preparedness for COVID-19 in health care settings. ET Report, editor. Solna Sweden: ECDC; 2020

6. Agalar C, Engin DO. Protective measures for COVID- * 19 for healthcare providers and laboratory personnel,". Turk J Med Sci. 2020;50 (1):564-578. doi:10.3906/sag-2004-132

7. UNICEF. COVID-19 emergency preparedness and response, wash and infection prevention and control in health facilities guidance note. New York, NY, USA: UNICEF, Editor; 2020

8. Capital Ethiopia Newspaper. Coronavirus: WHO lists Ethiopia, 12 others as top-risk African nations. Available from: https://www.capita lethiopia.com/capital/coronavirus-who-lists-ethiopia-12-others-as-toprisk-african-nations/. Accessed March 12, 2021.

9. Aljazeera. Ethiopia confirms first coronavirus case. Available from:https://www.afro.who.int/news/first-case-covid-19-confirmed-ethiopia. Accessed March 22, 2021.
10. Ethiopian Monitor. Coronavirus: 3 New Cases Identified in Ethiopia; 2020. Available from: https://ethiopianmonitor.com/?s=Coronavirus $\% 3 \mathrm{~A}+3+\mathrm{New}+\mathrm{Cases}+$ Identified+in+Ethiopia. Accessed March 12, 2021.

11. WHO. Guidance on preparing workplaces for COVID-19; 2020.

12. Newsweek. Over 100 Doctors and Nurses Have Died Combating Coronavirus Across the World. Available from: https://www.news week.com/coronavirus-deaths-infections-doctors-nurses-healthcareworkers-medical-staff-1496056. Accessed February 25, 2021

13. Voice of America. Ethiopia Confirms First Case of Coronavirus. Available from: https://www.voanews.com/science-health/corona virus-outbreak/ethiopia-confirms-first-case-coronavirus. Accessed march 12, 2021.

14. Anadolu Agency. COVID-19: ethiopia closes schools, bans public events. Available from: https://www.aa.com.tr/en/africa/covid-19-ethio pia-closes-schools-bans-public-events/1767683. Accessed March 12, 2021.

15. Havva Ozturk EB. The occupational safety of health professionals working at community and family health centers. Iran Red Crescent Med. 2020.

16. Kassie BA, Eskeziaw Abebe Kassahun AA, Ayele AS, Belew AK. Poor COVID-19 preventive practice among healthcare workers in Northwest Ethiopia, 2020. Adv Public Health. 2020;2020:7.

17. Gebrezgiabher BB. Awareness of occupational hazards and utilization of safety measures among welders in Aksum and Adwa Towns, Tigray Region Ethiopia. J Environ Public Health. 2013;2019:7.
Risk Management and Healthcare Policy

\section{Publish your work in this journal}

Risk Management and Healthcare Policy is an international, peerreviewed, open access journal focusing on all aspects of public health, policy, and preventative measures to promote good health and improve morbidity and mortality in the population. The journal welcomes submitted papers covering original research, basic science, clinical \& epidemiological studies, reviews and evaluations,

\section{Dovepress}

guidelines, expert opinion and commentary, case reports and extended reports. The manuscript management system is completely online and includes a very quick and fair peer-review system, which is all easy to use. Visit http://www.dovepress.com/testimonials.php to read real quotes from published authors. 